\title{
The Notion Of 'Case’ From Traditional Grammar To Modern Grammatical Theories: A Critical Historical Review
}

Greg O. Obiamalu

Department of Linguistics, Nnamdi Azikiwe University, Awka, Nigeria.

ABSTRACT

gregobiamalu@yahoo.com

The notion of 'case' has been a controversial one, yet the grammatical terminology has survived right from traditional Grammar to the current grammatical theories. This paper critically examines the notion of case within different grammatical frameworks. Our interest is mainly on the role of syntax and semantics in case determination and the level of grammatical analysis (deep or surface) at which case is assigned. The paper looks at the notion of case as conceived in traditional grammar and the explores how the concept has been adapted to antecedent grammatical theories up to the Principles and parameters theory. The paper concludes that in all the grammatical models, Case has both syntactic and semantic relevance.

\section{Indexing terms/Keywords}

Case; Traditional Grammar; Semantic Roles; Case Filter; Principles; Parameters Theory;

\section{Academic Discipline And Sub-Disciplines}

Humanities, Linguistics, Syntax and Semantics

\section{SUBJECT CLASSIFICATION}

Linguistics

\section{TYPE (METHOD/APPROACH)}

\section{Critical Review}

\subsection{INTRODUCTION}

The term 'case' is a primitive concept in grammar. It originated from the Greek word 'ptois' meaning 'deviation', which translated into 'kasus' in latin. cf: Iyons (1968:289).

The etymology of the words 'case' has to do with 'lexical deviation'. In other words, the lexeme deviates from its normal form to reflect some grammatical relationships. This idea gave rise to the use of 'case' as a grammatical terminology.

The notion of case has been conceived in various ways by different grammarians, following developments in grammatical analysis. This paper sets to examine critically, the various notions of case as conceived in different grammatical frameworks. The rest of the paper is divided into five sections. Section 2 discusses the traditional notion of case, while section 3 looks at the treatment of case in the Aspects model of the generative grammar, developed in Chomsky (1965). Fillmore's 'Case Grammar' is highlighted also in this section. Section 4 takes a look at 'case' and other related concepts in the Principles and Parameters Approach, otherwise known as GB. Section 5 tries to compare the case notions across the grammatical models. Section 6 is the summary and conclusion.

\subsection{THE TRADITIONAL NOTION OF CASE}

All In the traditional grammar, 'case' was seen as the inflectional forms of nouns due to their different syntactic functions. According to the traditional grammarians, case was the most important inflectional categories of the noun, as tense was the most important inflectional category of the verb.

Consider (1) (a) and (b) below:
(1) (a) Caesar Belgas vincit
Caesar Belgians beats
'Caesar beats the Belgians'
(b) Belgae Caeserem tement
Belgians Caesar fear
'The Belgians fear Caesar'. 
The Latin data in (1) taken from Haegeman (1991:143), illustrate the two forms which NPs can take to reflect their different syntactic functions in the sentence. 'Caesar' and 'the Belgians' take two different forms in the subject and the object positions. When they function as subject, they are in the 'nominative' case and when they function as object, they are in the 'accusative' case.

Traditional grammar was interested only in the morphological inflections on nouns and base on this, different case forms were identified. Latin for example has six case forms. They include: Nominative, Accusative, Vocative, Genitive, Dative and Ablative. The 'nominative' is the case associated with the subject of the sentence, the 'accusative' is used to mark the object of a transitive verb, the 'dative' marks the indirect object, the 'vocative' is the case of address, the 'genitive' is the case of possession, while the 'ablative' though with a variety of functions, mainly marks the instrument with which something is done.

The case forms of Latin nouns are to some extent interdependent on gender and number. The table below illustrates the common pattern of declension found in Latin nouns in feminine, masculine and neuter gender.

Table 1: Latin case forms for feminine, masculine and neuter genders

\begin{tabular}{|l|l|l|l|}
\hline & 'girl' (feminine) & 'wolf' (masculine) & 'war' (neuter) \\
\hline Nominative & puella & lupus & bellum \\
\hline Vocative & puella & lupe & bellum \\
\hline Accusative & puellam & lupum & bellum \\
\hline Genitive & puellae & lupi & belli \\
\hline Dative & peullae & lupo & bello \\
\hline Ablative & puella & lupo & bello \\
\hline
\end{tabular}

cf Lyons (1968:290)

The table contains the singular forms of the nouns. The case and number morpheme are fused in Latin, such that it is not possible to be segmented into stem and suffixes marking particular case and particular number. The table also shows that all the case forms are not reflected on a particular noun. The pattern of declension on feminine nouns such as puella 'girl' differs from that of masculine (e.g. lupus 'wolf' or neuter (e.g. bellum 'war'). There is no difference between the Genetive and the Dative forms of 'girl'. The two cases are realized as 'puellae'. But such distinction is seen in 'wolf' and 'friend' as shown in (3) below:

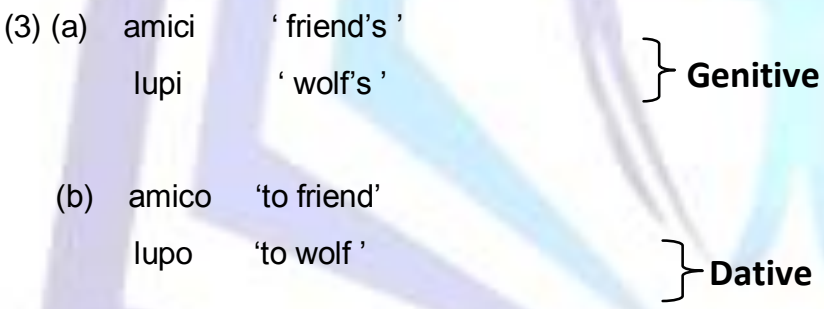

However, there are some languages such as Turkish which have a very regular pattern of declension. We shall not discuss that due to space constraint.

There is also a distinction in traditional grammar between 'grammatical' and 'local' case functions. While 'grammatical' implies the syntactic relations such as subjective, objective, possessive, etc. 'local' is understood to include temporal as well as spatial distinctions. The following local case are observed in Finnish, taking the noun 'tallo' 'house' for example.

Table 2: Finnish case forms for the word 'house'

\begin{tabular}{|l|l|l|l|}
\hline Interior & $\begin{array}{l}\text { Inessive } \\
\text { Elative } \\
\text { Illative }\end{array}$ & $\begin{array}{l}\text { tallosa } \\
\text { tallosta } \\
\text { talon }\end{array}$ & $\begin{array}{l}\text { 'in the house' } \\
\text { 'from (inside) the house } \\
\text { 'into the house' }\end{array}$ \\
\hline Exterior & $\begin{array}{l}\text { Adessive } \\
\text { Ablative } \\
\text { Allative }\end{array}$ & $\begin{array}{l}\text { talolla } \\
\text { talolta } \\
\text { tallolle }\end{array}$ & $\begin{array}{l}\text { 'at (or near) the house } \\
\text { 'from (outside) the house } \\
\text { 'to or towards the house' }\end{array}$ \\
& \multicolumn{2}{|c|}{ cf Lyons (1968:299) }
\end{tabular}

Finish marks with different case forms, the exact point of reference and direction of movement. This is shown by the agglutinating infixes - 1 - and-s-. 


\section{ISSN $2348-3024$

The traditional notion of case is limited to the morphological reflexes on nouns seen in some languages. But however, there are many languages, such as English, that do not show any morphological inflection on their noun to distinguish the different syntactic functions. Many people have argued that the traditional notion of case can be extended to such languages, though some people opposed to that. For example, Cassidy (1934:24) says that, "case will be properly used and will continue to have some meaning only if the association with inflection is fully recognized and if stretching on the term to include other sorts of formal distinction be abandoned".

However, the traditional case distinction has been extended to the so called 'caseless' languages. According to Fillmore (1968:156), prepositions in English or the absence of a preposition before a noun phrase, which may be treated as corresponding to a zero or unmarked case affix are selected on the basis of several types of structural features, and in ways that are exactly analogous to those which determine particular case forms in a language like Latin". Based on this assumption, the traditional case distinction was applied to other language with no overt case morphemes attached to the nouns. Some of the criteria for case distinction in such language are: the use of prepositions, and the relative word order, as in English. This is illustrated below:
(5)(a) The girl killed a snake (nominative)
(b) The snake bite the girl (Accusative)
(c) The doctor gave the girl some drug (Dative)
(d) The doctor gave some drugs to the girl (Dative)
(e) They lured the man with the girl (Ablative)
(f) The girl's bag is missing (Genitive)

Relative word order is used to indicate nominative, accusative and dative cases as in 5(a), (b) and (c). Alternatively, the Dative case can be indicated with the use of preposition 'to' as in (5) (d). The ablative is marked with the preposition 'with' as in (5)(e) and the genitive is shown by the use of 's' or alternatively by the use of the preposition 'of' as in (6) below:

\section{(6) The bag of the girl (Genitive)}

Applying the traditional case distinction of Latin to other language may be problematic. This is because the case system of one language differs from that of another. Fillmore (1968:5) observes that "looking for one man's case system in another man's language is not of course a good example of the study of case". Moreover, even in language with overt case markers, the number of case markers varies from language to language. There are two cases in old French, six in Latin, three in Hindi and Rumanian, five in ancient Greek, ten in Russian, eighteen in Hungarian, twenty six in Audi and Archi, and forty six in Tavassgrian (Mel'cuk (1986) in kiefer (1992:217).

\subsection{CASE IN GENERATIVE GRAMMAR}

Chomsky (1957:1965) developed a system of rules for generating infinite number of sentences in a language. This system of grammatical analysis is referred to as generative grammar.

Within this framework, the idea that case can be extended to languages without morphological inflections on their nouns is incorporated.

In the version of generative grammar developed in Chomsky (1965) popularly known as standard theory' or Aspects model, case is seen as a surface structure phenomenon and not present in the deep structure at all. It is merely the surface realization of particular syntactic relationships. These surface realizations include: noun inflections, prepositions, constraint on word order, etc. These surface reflexes are introduced by rules of various kinds of deep and surface syntactic relationships.

Let us take for example the English pronominal system that is morphological marked for case. The case form of pronoun is dependent on its surface syntactic relation. In other words, case form is assumed after transformation has taken place. Compare the two forms below:

(7) (a) John slapped him.

(b) He was slapped by John.

The two structures above are semantically similar. 'He' in $7(b)$ takes the nominative case due to the passive transformation which has moved the pronoun from its base position as the complement of the verb to the subject position. Similarly, the genitive case form, 'NP's' is assumed to have been introduced to accompany nominalization transformation as in (8).

(8) (a) Obi denied the allegation.

(b) Obi's denial of the allegation.

These show that case, according to the Aspects model is structurally assigned at the surface structure by means of prepositions, affixes, constraints on word order etc. 


\section{ISSN $2348-3024$ \\ Volume $7 \mathrm{Number} 1$ \\ Journal of Advances in Linguistics}

\subsection{Fillmore's Conception of Case}

Charles Fillmore in a number of interesting papers $(1968,1969,1971,1975,1977)$ developed an alternative model of generative grammar whose distinguishing feature is that 'case' is determined at the deepest syntactic level. A sentence consists of a verb and an unordered series of case relationships. The model is "a conception of base structure in which case relationships are primitive terms of the theory and in which such concepts as 'subject and 'direct object' are missing Fillmore (1968:3). This model is referred to as 'case grammar'.

Fillmore (1968) tries to justify why the term 'case' should be used to describe the deep semantic relationship, that exist in sentences. According to him, if the surface use of the term 'case' could capture the universal relationships that exist intrasententially, then surely there is no objection to using the word 'case' in the deep structure sense to capture the semantic information necessary for syntactic analysis. He based his arguments on two assumptions: 'the centrality of syntax' and 'the importance of covert categories' (Fillmore (1968:3))

Moreover, case grammar was developed due to the inability of the Aspect model in presenting both categorical and functional information pertaining to Prepositional Phrases. For example, Aspects has no way of showing that the PPs such as: 'in the house' to the church', 'by the robbers' are adverbials of location, direction and agent respectively. Case grammar captures the fact that the prepositions are case-markers that assign different case roles such as: agentive, locative, objective etc. Fillmore claimed in his earlier works that every NP even those which, as surface subjects, have no associated preposition) is associated with a prepositional case-marker (covert or overt) in the underlying structure.

The basic structure of a sentence according to Fillmore (1968) is as follows:
(9) Sentence
Modality + Proposition

The modality constituent will include such modalities on the sentence as a whole, such as: negation, tense, mode and aspect (p.23). Proposition on the other hand. " is a tenseless set of relationships involving verbs and nouns (and embedded sentences if any)' (p.23). This is represented in the general formula (10)

$$
\text { Proposition } \longrightarrow \text { verb }+ \text { case },+\ldots+\text { case }
$$

The case notions "comprise a set of universal, presumably innate concepts which identify certain types of judgments human beings are capable of making about the event that are going on around them, judgments about such matters as who did it, who it happened to and what got changed" (p.24.).

Below are some of the case roles identified by Fillmore and other case grammarians.

(11) (a) Agentive:

(b) Dative:

(c) Instrumental:

(d) Locative:

(e) Source:

(f) Goal:

(g) Objective:
The case of the instigator of an action.

The entity affected by the action.

The case of the means by which an action is performed.

The point where an event of the verb happened.

The point of origin of an entity.

The final destination of an entity

The case of anything representable by a noun. (This role is limited to things which are affected by the action or state identified by the verb)

The list above is not exhaustive. According to Cook (1977:299) "different lists indicate different ways in which case grammarians may choose to divide the continuum of semantic reality". The correct list of cases and how they should be defined are some of the problems in case grammar.

To summarize the basic idea in Case grammar, let us look at the following sentence.

$\begin{array}{cclll}\text { (12) Obi } & \text { bought } & \text { shoes } & \text { for Ada } & \text { from the market } \\ \text { (A)gent } & \text { verb } & \text { (O)bject } & \text { (D)ative } & \text { (L)ocative }\end{array}$

(12) will have the following deep structure representations.

1127 | $\mathrm{P}$ a g e

A ugust 2016 council for Innovative Research

w w w. cirworld. com 


\section{(13)}

( $\mathrm{k}=$ prepositional case marker)

The nature of ' $k$ ' depends on the case category. The typical case-marker for 'agentive' is 'by', objective is ' $\varnothing$ ', dative is 'for'. etc. Nilsen (1973) notes that case determination by preposition is misleading. This is because cases abound in languages where the same preposition marks different cases or where the same case role is signaled by different prepositions. He gave the following examples where the instrumental case role is marked by different prepositions in English.

(14) (a) I hit him with a rake

(b) He made the trip by auto

(c) He came the whole way in a car

(cf Nilsen (1973:84)).

The need for clearer criteria for case determination led to some modifications in case grammar. For example, the prepositions are no longer accepted as part of the deep structure, a position reaffirmed by Fillmore(1975:6) and (1977:64). The most important modification in case grammar is the employment of semantic features as yardstick for case determination. Nilsen (1972) is the first to propose these semantic features. According to him, 'since case grammar has a language independent semantically determined base, it is reasonable to assume that case assignment should be determined by semantic features (Nilsen (1973:86)).

The use of semantic features in case determination has been widely accepted. Some case grammarians such as Omamor(1977), Uwalaka (1988) etc. have proposed some modifications of the semantic features to take care of the lesser known languages. The list and definition of these semantic features cannot be handled in this short paper.

There is also the distinction between propositional and modal cases. According to Cook (1977:299). "propositional cases are required by the semantic valence of the verb... Modal cases are cases not required by the semantic valence of the verb. They include: time, manner, instrument, cause, purpose, result, etc. The modal cases are also referred to as adverbial cases.

Case grammar has some advantages over the Aspects version of the generative grammar. Newmeyer (1980:129-130) lists some of the benefits which Fillmore felt would accrue by taking case to be a primitive notion. Case grammar has semantic, syntactic as well as lexical benefits over the standard theory.

Case Grammar captures the deep semantic relationships which NPs bear to the verb irrespective of their surface syntactic function or position. Consider the following sentences from Igbo.

(15) (a) Òbi kụ̀wàrà afere

Obi break-rV(past) plate

'Obi broke a plate'

(b) Afere kụ̀wàrà n'aka Obi

Plate break-rV(past) in hand Obi

'A plate broke under Obi's care'

(16) (a) Àdha kụ̀jì̀ì aka

Ada beat-off-Rv part hand'

'Adha (accidentally) broke her hand'

(b) Aka kụjììi Àdha 


\section{SSN $2348-3024$ \\ Volume $7 \mathrm{Number} 1$ \\ Journal of Advances in Linguistics}

hand break-off-rV(past) Adha

'Adha (accidentally) broke her hand'

(Uwalaka (1988:45))

While (15) involves ergativity, (16) involves 'subject-object switching' a feature of some lgbo verbs with the semantic feature //- intent // (cf Uwalaka (1988:43-52)). Standard theory has no way of accounting for the deep structure similarity between the (a) and (b) sentences above. In case grammar, 'afere' is assigned the case role of 'Objective' in the two sentences, irrespective of the fact that it appeared as the subject in (15) (b). 'Adha' is assigned the deep case role of 'Experiencer' irrespective of the position where it occurs in the sentence.

Case Grammar also has some syntactic benefits. It is possible to predict using case information, which NP will become the subject if more than one NP occur in a sentence. The following case hierarchy holds for English. cf: Fillmore (1971:42).

(17) Agent $>$ Experiencer $>$ Instrument>Object $>$ Source $>$ Goal $>$ Location $>$ Time

If a sentence has two or more NPs, the one with the case role higher on the hierarchy will become the subject. This hierarchy also holds for lgbo. This could explain why the following sentences are deviant.

$$
\begin{aligned}
& \text { (18) * (a) àkwa kụ̀wàrà Àdha } \\
& \text { Egg break-rv(past) Ada } \\
& \text { Object }
\end{aligned}
$$

*(b) akwà zụ̀rụ̀

Òbi

Cloth buy - rVpast

Object

Obi

Agent

The objective NPs are chosen as subjects whereas the sentences contain Agentive NPs and so leads to ungrammaticality.

Case grammar, also has some lexical benefits. In this model, verbs in the lexicon could be associated with their case frames. For example, the verbs 'put' and 'sleep' must have the following case frame.

(19) (a) Put: $+[A+0+L]$

(b) Sleep: $+[\mathrm{E}]$

The verb 'put' takes obligatorily Agent, object and Locative NPs while only experiencer NP is compulsory with 'sleep'

Just like any other grammatical model, case grammar has met some criticism which I will point out here. First, there is no agreement among case grammarians on the number of cases identifiable in human language and how they should be defined. Anderson (11971) lists four cases, Fillmore (1968) lists six cases, Chafe (1970) lists seven cases and so on. Second, liefrink (1973:14) argues that case grammar is theoretically inadequate. According to him, "Case grammar assumes the verb to be deep structure category and also associates cases which are names for semantico-syntactic categories with the noun phrase and not with the sentence. This argument seems to be weak because Liefrink did not propose any other way of disassociating case from noun phrases. Even in the Government and Binding theory which is a later development and modification of the generative grammar, case and theta roles are structurally assigned by the sentence but associated with the noun phrases.

That notwithstanding, case grammar could not account for certain NPs associated with verbs. Fillmore himself noted towards the end of his work (Fillmore (1968)), that his proposed model (case grammar) could not adequately account for the so called 'cognate NPs' seen in languages like lgbo.

(20)
(a) Òkekē gbàrà ọsọ
Okeke run rVpast running
'Okeke ran'
(b) Ùgò hìrì ụra
Ugo sleep -rV(past) sleep
'Ugo Slept'
$\begin{array}{lll}\text { (c) Èmeka bùrù } & \text { ibù } \\ \text { Emeka be big-rV(past) } & \text { bigness }\end{array}$

'Emeka is big' 
The cognate NPs underlined form part of the complex predicates in Igbo, $V_{+} \mathrm{N}$. The NP has no associated case roles confirmed by their English translations that lack such NPs. This means that the syntax of deep case roles could not account for such surface NPs.

\subsection{CASE IN THE PRINCIPLES AND PARAMETERS FRAMEWORK}

As research activities continue to probe deeper into the nature of human languages, there arose the need to narrow down the various alternatives rules in linguistics analysis and also to shift emphasis from the system of rules to that of principles. These principles are the properties of Universal Grammar (UG).

Chomsky (1981) proposes a framework in which these principles interact to define for each language which structures are possible and which are not. There are also different parameters of a particular principle which account for the differences in language. This principles and parameters approach to grammar was nicknamed 'Government and Binding (GB) Theory'.

GB has different modules or subtheories of which 'case' is one of them. Others are: theta, x-bar, binding, government, control and bounding theories. These theories, though they operate on the same configuration independent of each other, interact to define for each language which structures are possible and which ones are not.

In this paper, our interest will be focused mainly on two subtheories: case and theta theories, for they are the two theories that relate to the notions of case which we have discussed earlier in this paper.

Case theory is the incorporation of the traditional notion of case into grammar. They only difference is that GB assumes case to be an abstract universal property of NPs whether morphologically marked or not. Therefore, there is a shift of emphasis from form to structure in case theory.

The idea behind case theory is that whether case is morphologically marked or not, an overt nominal element is assigned case by virtue of its position in a sentence. In fact, if an overt NP fails to be assigned Case or fails to appear in a position where case can be assigned, then the structure is adjudged ill-formed. This is stated in a principle called 'case filter'.

(21) Case filter

${ }^{*} \mathrm{NP}$, if NP has phonetic matrix and has no case.

Chomsky (1981:49)

This simply means that any overt NP (for there are covert NPs) must be case-marked. Case is assigned under government which is a structural relationships between NPs and their c-commanding heads. For a further discussion on government and c-command, see Chomsky (1981), Radford (1988) etc.

The basic picture of case assignment in GB can be illustrated with the following lgbo sentence.

(22) Òkekē gbùrù mmadụ̀ n' ọhia

Okeke kill-rv(past) person in bush

'Okeke killed somebody in the bush'

(23)

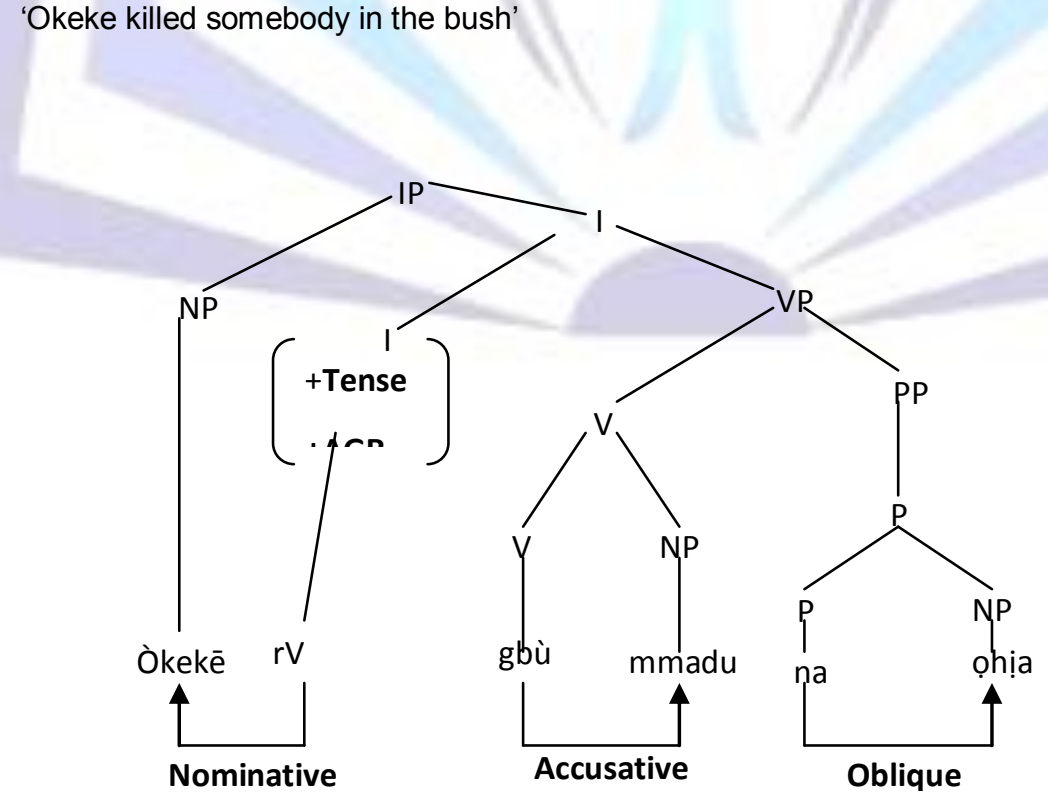

From the tree diagram in (23), we can see that the governing case assigners are always adjacent to the NPs which they case-mark. The case-assigning governors are lexical heads such as: verbs and prepositions and [+ Tense] INFL head. While [+ Tense] INFL assigns Nominative case to the subject NP, the verb and the preposition assign Accusative and 


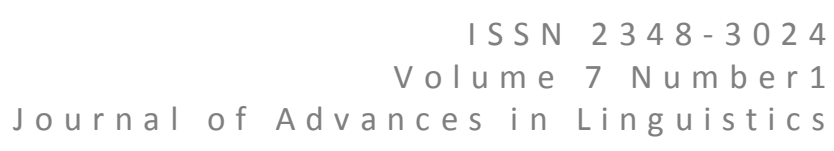

Oblique respectively to their complement NPs (though in some languages, there is no difference between the case assigned by the verb and that assigned by the preposition; they both assign Accusative case).

[-Tense] INFL is not a case-assigner. That could explain why the subject of an infinitival clause could only be occupied by a covert NP referred to as PRO. A structure such as (24) violates the case filter.

*(24) John to be foolish

This sentence can be redeemed by providing a case assigner outside the clause as in (25).

(25) For [IP John to be foolish] .....

(25) Is an example of Exceptional case marking (ECM) because IP ought to be a barrier to government and consequently case-assignment. The prepositional complementizer 'for' governs and assigns case to 'John' from outside the IP. However, in Igbo, sometimes an overt NP may appear as the subject of an infinitival clause without any overt case assigner as in (26).

(26) mmadụ igbū onwe yā jọ̀rọ̀ njọ

somebody to kill himself is bad

'For somebody to kill himself is bad'

Uwalaka (1995) argues that there is a null prepositional case-assigner in Igbo that license such NPs (for more details of the argument, see Uwalaka (1995)).

Theta theory on the other hand is a module in GB which incorporates Fillmore's notion of deep case roles into an independent module of grammar. These deep case roles are renamed theta $(\theta)$ - roles. Theta theory is concerned with the fundamental logical notion 'argument of' and it deals with the functional relationships between a predicate and its arguments. Theta-role are specified in the lexicon in the D-structure.

Theta theory interfaces with syntactic structure at both D-structure and S-structure and with meaning at logical form (LF). There is a requirement that all lexical information should be represented at all levels known as Projection Principle. Thetaroles are projected from the D structure to the S- structure where it can interact with case theory, for example in passive constructions.

(27) (a) e was killed the man (D-structure)

(b) The Mani was killed $t_{i}$ (S-structure).

In the D-structure of the sentence, 'the man' is base-generated as the complement of the verb 'kill'. The verb assigns the $\theta$ - role of theme to 'the man'. But at the S-structure, where case filter applies, the NP has to move in want of case because passive verb forms have lost the ability to assign case. It moves to the subject position where it is assigned Nominative case by the [+ Tense] INFL head.

Theta-roles are certain thematic functions which NPs bear to their verbs. The thematic functions include: Agent, Patient (or Theme), Location, Source, Goal, Path etc. There is no general agreement just like in Case grammar over the number of $\theta$ - roles required to describe all the thematic relations in human languages.

\subsection{Case as a Functional Head}

With recent developments in the Principles and Parameters Approach especially in the $\mathrm{x}$ - bar theory, it is discovered that apart from lexical heads, there could be functional elements which can be maximally projected just like the lexical heads. Such functional heads include: (AGR)eement ( $\mathrm{T}$ )ense, (NEG)ation (K)ase, to mention but a few.

Dechaine (1997:6) following Abney's (1987) 'NP hypothesis' (a replacement for NP) and Chomsky's (1995) assumption that lexical verbs are not a source of case, she proposes that "direct objects are case-marked by Kase, the (null) head of a KP Projection between V and DP" as in 28. 
$(28)$

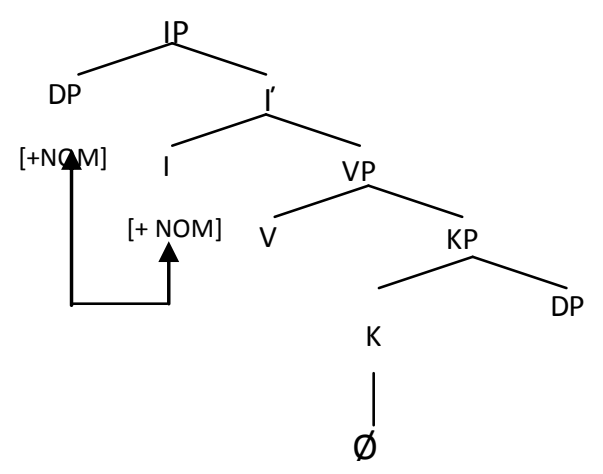

cf Dechaine (1997:6)

The implication of this new analysis is that we are going back in assuming 'case' as a base generated phenomenon.

\subsection{COMPARISON OF THE CASE NOTIONS ACROSS THE GRAMMATICAL MODELS}

GB incorporates the traditional notion of case as a surface structure phenomenon but differs from traditional grammar in taking case as an abstract universal property of every NP whether morphologically marked or not. Emphasis in GB is more on the structural relationship than on function. Base on this, only few case are recognized in GB: Nominative, Accusative, Oblique and Genitive. The case name is given base on the type of case-assigner. Apart from Genitive case which is inherently assigned, others are structurally assigned by different governing heads.

GB also incorporates the idea of case roles which are now termed theta-roles, but differs from case Grammar in the shift of interest from the definite semantic roles their surface realization to the satisfaction of the principle called thetacriterion.

\section{(29) Theta-criterion}

Each argument bears one and only one $\theta$-role and each

$\theta$-role is assigned to one and only one argument.

$$
\text { cf Chomsky (1981:36) }
$$

The $\theta$-criterion could be comparable with Fillmore's statement about case-roles which says that "at least one case category must be chosen and where no case category appears more than once in a sentence" (Fillmore 1968:24).

The cognate NPs which do not have case roles (or $\theta$ - roles) could be accounted for in GB by the case theory which operates only in the surface structure and assigns Accusative case to such NPs that lack case-roles ( $\theta$-roles).

\subsection{SUMMARY AND CONCLUSION}

In this paper, we have been able to show that the notion of case has been conceived in different ways in the different grammatical frameworks. The points of disagreement are whether case is syntactically as well as semantically relevant and whether case is a base structure or surface structure phenomenon.

Traditional grammar accepts that case is syntactically as well as semantically relevant but applicable only to surface structure and must show some morphological reflexes. Aspects model of generative grammar agrees with traditional grammar in saying that case in only applicable in the surface but differs in proposing that case is governed by some rules of various kinds of deep and surface syntactic relations.

Case grammar, on the other hand, is entirely a different approach to the notion of case. Here, case is semantically and syntactically relevant, determined in the deep structure and marked in the surface by different means as affixation, preposition, suppletion, relative word order etc.

In the Principles and Parameters framework (i.e. GB), the notions of case in the traditional grammar and in Fillmore's case Grammar are integrated into two modules of grammar: case and theta theories. Case has also been conceived as a functional category in the later frameworks. 
We can conclusively say that the notions of case in all the grammatical frameworks we have discussed have the centrality of the verb as the basic idea behind case assignment and case realization. Even the Nominative Case depends on the externalization of a $\theta$-role by predication. Therefore case has deep as well as surface syntactic relevance.

\section{REFERENCES}

1. Abney, Steven A. 1987. The English Noun Phrase in its Sentential Aspect, Dissertation, M.I.T.Cambridge, MA

2. Anderson, J.M. 1971. The Grammar of Case. Cambridge, England: Cambridge University Press.

3. Chomsky, Noam.1965. Aspects of the theory of Syntax. Cambridge MA: MIT Press.

4. Chomsky, Noam. 1981. Lectures on Government and Binding. The Pisa Lectures, Dordrecht: Foris.

5. Cook, Walter A. 1978. A case Grammar Matrix Model. In W. Abraham (ed.) Valence, Semantic Case and Grammatical Relations. Studies in Language Companion Series 1, Amsterdam: John Benjamin, 295-309.

6. Dechaine, Rose-Marie. 1997. On the left edge of Yoruba Complements. A paper presented at a Round-table conference on complementation, Department of Linguistics and African Languages, University of Ibadan, Oct.1997.

7. Fillmore, Charles .J. 1968. The case for case. In E. Bach and R.T. Harms (ed.) Universals in Linguistic Theory. New

York: Rinehart and Winston,1-88.

8. Fillmore, Charles .J. 1969. Towards a Modern Theory of Case. In D.A. Reibel and S.A. Schane (eds) Modern Studies in English.

9. Fillmore, Charles .J. 1971. Some problems for Case Grammar. In R.J. O' Brien (ed.) Monograph series on Language and Linguistics_No.24 Washington D.C. Georgetown University Press, 35-56.

10. Fillmore, Charles .J. 1977. The case for case reopened. In P. Cole and J.M. Saddock (eds.) Syntax, Semantics and

Grammatical Relations, vol.8. New York: N.Y. Academic Press, 59-82.

11. Gruber, J.S. 1965. Studies in Lexical Relations. MIT PhD Dissertation.

12. Gruber, J.S. 1990. Complex Thematic Structures. Cambridge MA: MIT Press.

13. Haegeman, Liliane. 1991. Introduction to Government and Binding Theory. Cambridge, MA: Basil Blackwell Inc.

14. Kiefer, F. 1992. Case. in W. Bright (ed.) International Encyclopedia of Linguistics, vol.2 New York:

15. Liefrink, F.M. 1973. Semantico Syntax. London: Longman.

16. Lyons John. 1968. Introduction to Theoretical Linguistics. Cambridge England: Cambridge University Press.

17. Newmeyer, F. J. 1980. Linguistic Theory in America. New York: Academic Press Inc.

18. Nilsen, D.L. 1972. Towards a Semantic Specification of Deep Case. Janua Linguarum, Series Minor, 152 Paris: Mouton The Hague.

19. Nilsen, D.L 1973. The Instrumental Case in English Paris: Mouton, The Hague.

20. Omamor, A. .P. 1978. Case Grammar and Viability. In W. Abraham (ed.) Valence, Semantic Case and Grammatical

Relations, Studies in Language Companion Series 1, Amsterdam: John Benjamins, 261-293.

21. Radford, Andrew 1988. Transformational Grammar. Cambridge: Cambridge University Press.

22. Uwalaka, M.A. 1988. The Igbo Verb: A Semantico - Syntactic Analysis. Beitrage Zur Afrikanistik, Nr 48 Band 35.

23. Uwalaka, M.A. 1995. Null Case Assigners in Igbo. A paper presented at the Colloquim in honour of Prof. Ayo Banjo,

Conference Centre, University of Ibadan November, 1995. 
24. Webelhuth, Gert. 1995. X-bar Theory and Case Theory. In G. Webelhuth (ed.) Government and Binding Theory and

The Minimalist Program. Cambridge, Mass: Basil Blackwell Inc. 15-95.

\section{Author's biography with Photo}

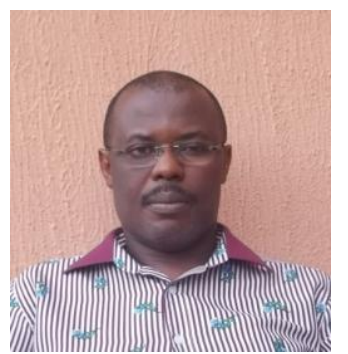

Greg O. Obiamalu (BA, MA, PhD) is an Associate Professor of Linguistics at Nnamdi Azikiwe University, Awka, Nigeria. He is the current Head, Department of Linguistics, Nnamdi Azikiwe University, Awka. His area of specialization is syntax. He has research interest in other areas like contact languages and language documentation. He has published over 30 articles in reputable journals 